\title{
KARAKTERISTIK PENDONOR DARAH YANG GAGAL PENGAMBILAN DARAH SAAT DONASI DI UTD PMI SLEMAN
}

\author{
${ }^{1}$ Suci Cahyani, ${ }^{2}$ Suci Ihtiaringtyas \\ Program Studi Teknologi Bank Darah (D-3) Fakultas Kesehatan \\ Universitas Jenderal Achmad Yani Yogyakarta \\ Email: cahyasuci69@gmail.com, suciihtiaringtyas@gmail.com
}

\begin{abstract}
ABSTRAK
Kebutuhan darah di Kabupaten Sleman sekitar 1.000 kantong darah setiap bulan. Sedangkan produksi darah di UTD PMI Kabupaten Sleman sekitar 11.500 kantong darah belum lagi dikurangi dengan kantong darah yang harus dimusnahkan sekitar 1.500 kantong darah yang salah satu penyebabnya karena gagal pengambilan darah. Pendonor darah yang gagal dilakukan pengambilan darah tersebut kemudian dilakukan pencatatan di SIMDONDAR UTD PMI Kabupaten Sleman, selanjutnya digolongkan sesuai dengan karakteristis pendonor darah. Penelitian ini bertujuan untuk mengetahui karakteristik pendonor darah yang gagal pengambilan darah berdasarkan jenis kelamin, usia, golongan darah, dan jumlah donasi darah di UTD PMI Kabupaten Sleman tahun 2019. Penelitian ini merupakan penelitian kuantitatif non eksperimental melalui pendekatan retrospektif untuk membuat deskripsi secara objektif dengan melihat data yang sudah terdokumentasi sebelumnya. Sampel pada penelitian ini berjumlah 146 pendonor darah yang gagal dalam pengambilan darah di UTD PMI Kabupaten Sleman. Pengambilan sampel dilakukan menggunakan teknik total sampling. Pendonor yang gagal pengambilan darah di UTD PMI Kabupaten Sleman sebanyak $146(1,27 \%)$ pendonor darah. Kelompok yang memiliki jumlah pendonor darah yang gagal pengambilan darah paling tinggi adalah pendonor darah dengan jenis kelamin laki-laki $(55,63 \%)$, pendonor darah pada masa remaja akhir dengan usia 17-25 tahun $(47,18 \%)$, pedonor dengan golongan darah B rhesus positif $(35,92 \%)$ dan pendonor darah ulang (51.41\%). Maka dari itu, pendonor darah diharapkan lebih mempersiapkan diri jika ingin mendonorkan darahnya karena ada kemungkinan-kemungkinan terjadinya kegagalan dalam pengambilan darah.
\end{abstract}

\section{Kata kunci : Donor Darah, Seleksi Pendonor Darah, Gagal Donor}

\section{ABSTRACT}

The need for blood in Sleman Regency is around 1.000 bags blood every month. Meanwhile, the blood production at Indonesian Red Cross Blood Transfusion Service Sleman Regency is around 11.500 blood bags not to mention reduced by the blood bags that must be destroyed around 1.500 blood bags, one of the causes is due to failed to blood draw. Blood donors who failed to blood draw were then recorded at blood donor management information system (SIMDONDAR) Indonesian Red Cross Blood Transfusion Service Sleman Regency, and then classified according to the characteristics of blood donors. This study aims to determine the characteristics of blood donors who failed to blood draw based on gender, age, blood type, and number of blood donors at Indonesian Red Cross Blood Transfusion Service Sleman Regency in 2019. This research is a non-experimental quantitative study with a retrospective approach to create an objective description by looking at previously documented data. The sample in this study were 146 blood donors who failed to blood draw at Indonesian Red Cross Blood Transfusion Service Sleman Regency in 2019. Sampling using total sampling technique. There were 146 (1,27\%) blood donors who failed to blood draw at Indonesian Red Cross Blood Transfusion Service Sleman Regency in 2019. The group that had the highest number of blood donors who failed to blood draw was male blood donors (55,63\%), blood 
Vol.2.No 2 (2020) p-ISSN :2657-2435 e-ISSSN:2721-3145

donors in late adolescence aged $17-25$ years $(47,18 \%)$, blood donors with blood group $B$ rhesus positive $(35,92 \%)$ and regularly blood donors $(51,41 \%)$. Therefore, blood donors are expected to be more prepared if they want to donate blood because there are possibilities for failed to blood draw

Keywords : Blood Donation, Blood Donor Selection, Blood Donor Failfure 


\section{PENDAHULUAN}

Pelayanan darah merupakan upaya yang dilakukan untuk pelayanan kesehatan yang memanfaatkan darah manusia sebagai bahan dasar untuk pengobatan dengan tujuan kemanusiaan tanpa tujuan komersial (Menteri Kesehatan RI, 2014). Darah tersebut diperoleh dari pendonor darah yang mendonorkan darahnya. Dilakukan pengolahan darah oleh Unit Transfusi Darah yang diselenggarakan oleh Palang Merah Indonesia (Presiden RI, 2011).

Darah dan komponen darah yang tersedia didapatkan dari pendonor darah sukarela, sisanya dipenuhi dari pendonor darah pengganti yang berasal dari keluarga atau pendonor darah bayaran (Pusdatin Kemenkes, 2018). Sebelum darah ditransfusikan ke pasien, terlebih dahulu dilakukan pengambilan darah vena pada lengan pendonor darah. Pengambilan darah pada pendonor darah adalah tusukan ke pembuluh darah vena untuk tujuan mengambil darah yang digunakan untuk keperluan transfusi (Mbah, 2014). Pengambilan darah harus memperhatikan keselamatan pendonor darah, terkait dengan jumlah darah yang diambil dan jangka waktu pengambilan darah. Tindakan medis pengambilan darah hanya dilakukan di UTD PMI dan atau tempat tertentu yang memenuhi persyaratan kesehatan dan harus dilaksanakan oleh petugas pelayanan darah atau tenaga kesehatan yang berwenang sesui standar (Presiden RI, 2011). Hanya donor yang telah diperiksa saat sebelum pengambilan darah dan memenuhi kriteria seleksi donor yang ditetapkan UTD yang diperbolehkan untuk dilakukan pengambilan darah. Pendonor darah harus diidentifikasi kembali sebelum penusukan dimulai dan darahnya ditampung didalam kantong darah steril yang telah disetujui oleh petugas kompeten dan terlatih menggunakan prosedur yang telah divalidasi (Menteri Kesehatan RI, 2016).

Tindakan pengambilan darah tidak selalu berhasil, kadang-kadang juga mengalami kegagalan dalam pengambilan darah. Kegagalan pengambilan darah didefinisikan sebagai penyisipan jarum yang gagal ke dalam vena dan gangguan pengambilan darah apapun karena durasi yang berkepanjangan atau faktor lain yang terkait dengan teknik penusukan vena atau reaksi vasovagal. Penusukan vena dan pengambilan darah biasanya berhasil dilakukan pada upaya kedua dengan adanya persetujuan dari donor, tidak diklasifikasikan sebagai kegagalan pengambilan darah. Kegagalan tersebut bisa disebabkan oleh ujung jarum tidak berada pada pembuluh vena, vena bergerak-gerak saat ditusuk sehingga tempat penusukan vena tidak tepat, ataupun ukuran vena yang kecil (Kiswari, 2014).

Pada tahun 1998, Crosia memiliki tingkat kegagalan pengambilan darah sebanyak $1,47 \%$ dan terus menurun hingga $0,5 \%$ pada tahun 2001 sebagai hasil pendidikan petugas pengambilan darah yang tepat (Vuk et al., 2015). Sedangkan tahun 2010, terdapat 471 pengambilan darah yang gagal. Berarti kegagalan pengambilan tersebut menyumbang $51 \%$ dari semua ketidaksesuaian dalam pelayanan darah yang telah dicatat (Vuk, 2011). Selama periode 2002 sampai dengan 2013 insiden kegagalan pengambilan darah bervariasi dari $0,52 \%$ hingga $0,92 \%$ (Vuk et al., 2015).

Kegagalan pengambilan darah dan reaksi yang merugikan tidak hanya mengurangi suplai darah berharga yang tersedia untuk perawatan transfusi darah, tetapi juga akan mencegah sumbangan darah di masa depan (Vuk et al., 2015). Berdasarkan standart WHO, Indonesia memiliki jumlah kebutuhan darah minimal sekitar 5,1 juta kantong darah pertahun. Artinya $2 \%$ dari jumlah penduduk yang ada di Indonesia. Sedangkan produksi darah dan pembuatan komponen darah menghasilkan sebanyak 4,1 juta kantong darah dari 3,4 juta kantong darah lengkap (Depkes RI, 2017). Pada tahun 2016 hanya 5 provinsi dari 34 provinsi di Indonesia yang kebutuhan darahnya telah terpenuhi yaitu provinsi DKI Jakarta, Yogyakarta, Jawa Timur, Bali, dan Kalimantan Timur. Provinsi Yogyakarta memproduksi 113.390 kantong darah dari 74.418 kantong darah yang dibutuhkan (Pusdatin Kemenkes, 2018). PMI Kabupaten Sleman, menargetkan 1,2\% dari 
jumlah penduduk Sleman sebanyak 1,1 juta penduduk menjadi pendonor darah. Tahun 2019 jumlah pendonor di UTD PMI Kabupaten Sleman baru sekitar 1\% dari jumlah penduduk di Sleman. Sedangkan kebutuhan darah di Kabupaten Sleman sekitar 1.000 kantong setiap bulan. Dan tahun 2019 produksi darah di UTD PMI Kabupaten Sleman sekitar 11.500 kantong darah. Jumlah kantong darah yang dimusnahkan sekitar 1.500 kantong darah yang disebabkan oleh gagal pengambilan darah, pemeriksaan IMLTD (Infeksi Menular Lewat Transfusi Darah) reaktif, darah kadaluwarsa, dan masalah dalam proses produksi. Kantong darah yang dimusnahkan tersebut dapat berdampak kerugian materiil, seperti kantong darah yang belum bisa membuat sendiri dan masih import dari luar negeri, saat pemeriksaan kesehatan sederhana atau seleksi donor yang menggunakan bahan sekali pakai. Pada waktu-waktu tertentu, seperti awal tahun, bulan Ramadan, seminggu sampai dua minggu setelah lebaran sering terjadi trendnya penurunan jumlah pendonor darah. permintaan darah yang cenderung tetap tetapi jumlah pendonor darah yang terjadi penurunan Karena waktu-waktu tersebut termasuk libur panjang, bisa digunakan untuk mudik atau liburan, ditambah dengan terdapat waktu-waktu tertentu, seperti awal tahun, bulan Ramadan, seminggu sampai dua minggu setelah lebaran sering terjadi trendnya penurunan jumlah pendonor darah. Permintaan darah yang cenderung tetap tetapi jumlah pendonor darah yang terjadi penurunan karena waktu-waktu tersebut termasuk libur panjang, bisa digunakan untuk mudik atau liburan.

Jumlah penduduk di Kabupaten Sleman termasuk yang tertinggi se-Daerah Istimewa Yogyakarta sekitar 1,1 juta penduduk, banyak penduduk Kabupaten Sleman yang menjadi pendonor darah di UTD PMI Kabupaten Sleman dan memberikan peluang banyak juga kegagalan pengambilan darah yang dilakukan ke pendonor darah. Dan berdasarkan studi pendahuluan yang dilakukan di UTD PMI Kabupaten Sleman jumlah kegagalan dalam pengambilan darah tahun ketahun jumlahnya meningkat. Pada tahun 2018 jumlah kegagalan dalam pengambilan darah adalah 117 kegagalan dan tahun 2019 jumlah kegagalan dalam pengambilan darah adalah 146 kegagalan. Berdasarkan hasil studi pendahuluan yang didapatkan, kegagalan dalam pengambilan darah bisa saja mengurangi stok darah yang ada di UTD PMI Kabupaten Sleman. Padahal dalam keadaan atau waktu tertentu seperti yang dijelaskan diatas masih kekurangan stok darah. Untuk itu perlu ada kesadaran dari masyarakat umum akan pentingnya donor darah. Masyarakat umum memiliki kesadaran menjadi pendonor darah rutin selama 2 bulan sekali. Kegiatan donor darah diikuti untuk kalangan umum tanpa memandang perbedaan jenis kelamin dan usia yang memenuhi syarat donor darah. Kesadaran menjadi pendonor darah rutin ini tentunya baik bagi kesehatan pendonor sendiri, selain itu akan terpenuhi kebutuhan darah di Indonesia. Sebagai Pendonor darah harus dilakukan tindakan pengambilan darah pada lengan pendonor darah. Dan tindakan pengambilan darah tidak selalu berhasil, kadang-kadang juga mengalami kegagalan dalam pengambilan darah yang dilakukan pada pendonor darah. Pendonor darah yang gagal dilakukan pengambilan darah tersebut kemudian dilakukan pencatatan di Sistem Informasi Manajemen Donor Darah (SIMDONDAR) UTD PMI Kabupaten Sleman, selanjutnya digolongkan sesuai dengan karakteristis pendonor darah yang akan diteliti.

Penelitian ini bertujuan Untuk mengetahui karakteristik pendonor darah yang gagal pengambilan darah di UTD PMI Kabupaten Sleman tahun 2019.

\section{METODE PENELITIAN}

Penelitian ini merupakan penelitian kuantitatif non eksperimental melalui pendekatan retrospektif untuk membuat deskripsi secara objektif dengan melihat data yang sudah terdokumentasi sebelumnya. Lokasi penelitian adalah lokasi dari pelaksanaan kegiatan karya tulis ilmiah yang dilakukan di UTD PMI Kabupaten Sleman dengan alamat Jalan Dr. Radjimin, Sucen, Triharjo, Kecamatan Sleman, Kabupaten Sleman, Daerah Istimewa Yogyakarta. 
Populasi dalam penelitian ini adalah seluruh pendonor darah yang gagal pengambilan di UTD PMI Kabupaten Sleman selama tahun 2019 yang telah terdokumentasi di Sistem Informasi Manajemen Donor Darah UTD PMI Kabupaten Sleman yaitu sebanyak 146 pendonor darah yang gagal dalam pengambilan darah. Pengambilan sampel dilakukan menggunakan teknik total sampling. Sampel pada penelitian ini berjumlah 146 pendonor darah yang gagal dalam pengambilan darah, dengan kriteria tercatat di dalam Sistem Informasi Manajemen Donor Darah UTD PMI Kabupaten Sleman dan memiliki data dokumentasi lengkap.

Metode pengumpulan data yang dilakukan pada penelitian ini adalah studi dokumen berupa data sekunder. Menganalisis data sekunder karakteristik pendonor darah yang gagal pengambilan darah yang sudah terdokumentasi di UTD PMI Kabupaten Sleman selama tahun 2019 kemudian akan diolah menggunakan perangkat komputer. Analisis data pada penelitian ini menggunakan analisis univariat.

\section{HASIL DAN PEMBAHASAN}

Berdasarkan data yang sudah didapatkan tentang pengambilan darah yang dilakukan di UTD PMI Kabupaten Sleman Tahun 2019 ditemukan hasil penelitian sebagai berikut:

\begin{tabular}{|c|c|c|}
\hline Kategori & $\begin{array}{l}\text { Frekuens } \\
\text { i }\end{array}$ & $\begin{array}{l}\text { Persentas } \\
\text { e }\end{array}$ \\
\hline $\begin{array}{l}\text { Berhasil } \\
\text { Aftap }\end{array}$ & 11.354 & $98.73 \%$ \\
\hline Gagal Aftap & 146 & $1.27 \%$ \\
\hline Total & 11.500 & $100 \%$ \\
\hline
\end{tabular}

Berdasarkan hasil penelitian diatas dari 11.500 pengambilan darah, persentase pengambilan darah yang berhasil dilakukan pada pendonor darah yaitu $98.73 \%$, sedangkan untuk pengambilan darah yang gagal dilakukan pada pendonor darah yaitu $1.27 \%$. Persentase pengambilan darah yang gagal dilakukan pada pendonor darah pada penelitian ini lebih tinggi dari penelitian yang dilakukan oleh Vuk et al. (2015) di Croatian Institute of Transfusion Medicine (CITM) yang dilakukan selama periode 2002-2013, dimana pada penelitian tersebut didapatkan persentase pengambilan darah yang gagal dilakukan pada pendonor darah bervariasi dari $0,52 \%$ hingga $0,92 \%$. Perbedaan ini kemungkinan karena pada tahun 1998 di CITM, persentase pengambilan darah yang gagal dilakukan pada pendonor darah yaitu $1,47 \%$, kemudian semenjak tahun 2001 terdapat pendidikan atau pelatihan pengambilan darah yang layak untuk petugas pengambilan darah dan persentase pengambilan darah yang gagal dilakukan pada pendonor darah terus menurun.

Karakteristik pendonor darah yang gagal dilakukan pengambilan darah menurut jenis kelamin di UTD PMI Kabupaten Sleman Tahun 2019 sebagai berikut:

Tabel 2 Distribusi Frekuensi Karakteristik Pendonor Darah yang Gagal Pengambilan Darah Menurut Jenis Kelamin di UTD PMI Kabupaten Sleman Tahun 2019

\begin{tabular}{lcc}
\hline $\begin{array}{c}\text { Jenis } \\
\text { Kelamin }\end{array}$ & $\begin{array}{c}\text { Frekuensi } \\
(\mathbf{n = 1 4 2})\end{array}$ & Persentase \\
\hline Laki-Laki & 79 & $55,63 \%$ \\
Perempuan & 63 & $44,37 \%$ \\
\hline Total & 142 & $100 \%$ \\
\hline
\end{tabular}

Berdasarkan tabel 2 terlihat bahwa jumlah pendonor darah yang gagal dilakukan pengambilan darah berjenis kelamin lakilaki yaitu sejumlah 79 pendonor darah $(55,63 \%)$, sedangkan yang gagal dalam pengambilan darah berjenis kelamin perempuan yaitu sejumlah 63 pendonor darah $(44,37 \%)$.

Hasil ini sesuai dengan data yang diperoleh dari UTD PMI Kabupaten Sleman bahwa pendonor laki-laki lebih banyak mendonorkan darahnya yaitu sebanyak 9.463 pendonor darah, daripada pendonor perempuan sebanyak 2.037 pendonor darah. Hal tersebut disebabkan pada perempuan memiliki syarat yang lebih banyak jika ingin mendonorkan darahnya dibandingkan dengan laki-laki. Perempuan yang sedang menstruasi, hamil, dan menyusui tidak diperbolehkan untuk 
mendonorkan darahnya (Menteri Kesehatan RI, 2016).

Karakteristik pendonor darah yang gagal dilakukan pengambilan darah menurut usia di UTD PMI Kabupaten Sleman Tahun 2019 sebagai berikut:

\begin{tabular}{ccc}
\multicolumn{2}{c}{$\begin{array}{c}\text { Tabel } 3 \text { Distribusi Frekuensi } \\
\text { Karakteristik Pendonor Darah yang } \\
\text { Gagal Pengambilan Darah Menurut } \\
\text { Usia di UTD PMI Kabupaten Sleman } \\
\text { Tahun 2019 }\end{array}$} \\
$\begin{array}{c}\text { Crekuensi } \\
\text { Usia } \\
\text { (tahun) }\end{array}$ & $\begin{array}{c}\text { Fre142) } \\
\text { (n=14) Persentase }\end{array}$ \\
\hline $17-25$ & 67 & $47,18 \%$ \\
$26-35$ & 31 & $21,83 \%$ \\
$36-45$ & 23 & $16,20 \%$ \\
$46-55$ & 14 & $9,86 \%$ \\
$56-65$ & 7 & $4,93 \%$ \\
\hline Total & 142 & $100 \%$ \\
\hline
\end{tabular}

Menurut data penelitian, pendonor darah paling muda yang gagal dilakukan pengambilan darah berumur 17 tahun dan pendonor darah tertua yang gagal dilakukan pengambilan darah berumur 62 tahun. Berdasarkan tabel 3 terlihat bahwa jumlah pendonor darah yang gagal dilakukan pengambilan darah tertinggi berada pada rentang usia 17-25 tahun yaitu sejumlah 67 pendonor darah $(47,18 \%)$, sedangkan yang gagal dalam pengambilan darah yang terendah berada pada rentang usia 56-65 tahun yaitu sejumlah 7 pendonor darah (4,93\%).

Pada hasil penelitian karakteristik pendonor darah yang gagal pengambilan darah menurut usia di UTD PMI Kabupaten Sleman, pendonor darah paling muda yang gagal dilakukan pengambilan darah berumur 17 tahun. Hal tersebut bisa disebabkan karena usia minimal untuk jadi pendonor darah adalah 17 tahun (Menteri Kesehatan RI, 2016), dipilihnya 17 tahun semata-mata karena alasan legalitas hukum yang berlaku di Indonesia bahwa usia 17 tahun adalah usia yang sudah memasuki kategori dewasa secara hukum, dianggap sudah cakap/dewasa untuk mengambil keputusan (Rachman \& Aditya, 2013).
Adapun secara medis usia dibawah 16 tahun tidak diperbolehkan mendonorkan darahnya karena pada usia tersebut masih membutuhkan zat besi yang tinggi, zat besi menjadi komponen utama dari pembentukan hemoglobin, memiliki peran dalam proses metabolisme tubuh, pertumbuhan dan perkembangan fungsi normal sel-sel tubuh, serta pembentukan hormone dan jaringan ikat (Sinde, 2014). Pendonor darah tertua yang gagal dilakukan pengambilan darah berumur 62 tahun. Hal tersebut bisa disebabkan karena untuk pendonor pertama kali atau yang jarang donor dengan umur maksimal 60 tahun, pasalnya organ tubuh orang tersebut belum terbiasa beradaptasi untuk membentuk sel darah baru seperti halnya yang rutin mendonorkan darahnya (Rachman \& Aditya, 2013). Adapun bagi pendonor ulang dengan umur maksimal 65 tahun dapat menjadi pendonor darah, pasalnya organ tubuh pendonor rutin telah terbiasa menyesuaikan diri untuk segera membentuk sel darah baru setelah mendonorkan darah. Pada usia 65 tahun organ tubuh masih berfungsi secara maksimal untuk pembentukan sel darah yang baru (Rachman \& Aditya, 2013). Sedangkan dari 142 pendonor darah yang gagal pengambilan darah, pendonor darah pada masa remaja akhir (17-25 tahun) termasuk yang paling banyak gagal dilakukan pengambilan darah yaitu sebanyak 47,18\% (67 pendonor darah). Hasil ini sesuai dengan data yang diperoleh dari UTD PMI Kabupaten Sleman bahwa pendonor pada masa remaja akhir (17-25 tahun) lebih banyak mendonorkan darahnya yaitu sebanyak 3.593 daripada pendonor darah masa dewasa atau lansia. Hal tersebut disebabkan pada masa remaja akhir (17-25 tahun), termasuk usia anak sekolah, mahasiswa, dan pekerja muda yang memiliki pengetahuan dan kesadaran untuk melakukan donor darah secara sukarela untuk membantu sesama manusia.

Karakteristik pendonor darah yang gagal dilakukan pengambilan darah menurut golongan darah di UTD PMI Kabupaten Sleman Tahun 2019 sebagai berikut. 
Tabel 4 Distribusi Frekuensi Karakteristik Pendonor Darah yang Gagal Pengambilan Darah Menurut Golongan Darah di UTD PMI Kabupaten Sleman Tahun 2019

\begin{tabular}{lcc}
\hline $\begin{array}{l}\text { Golongan } \\
\text { Darah }\end{array}$ & $\begin{array}{c}\text { Frekuensi } \\
(\mathbf{n = 1 4 2 )}\end{array}$ & Persentase \\
\hline $\mathrm{A}(+)$ & 27 & $19,01 \%$ \\
$\mathrm{~A}(-)$ & - & - \\
$\mathrm{B}(+)$ & 51 & $35,92 \%$ \\
$\mathrm{~B}(-)$ & - & - \\
$\mathrm{AB}(+)$ & 15 & $10,56 \%$ \\
$\mathrm{AB}(-)$ & - & - \\
O (+) & 49 & $34,51 \%$ \\
O (-) & - & - \\
\hline Total & 142 & $100 \%$ \\
\hline
\end{tabular}

Berdasarkan tabel 4 terlihat bahwa, dari 142 pendonor darah yang gagal pengambilan darah, pendonor darah bergolongan darah $B$ rhesus positif termasuk yang paling banyak gagal dilakukan pengambilan darah yaitu sebanyak 51 pendonor darah (35,92\%). Pendonor darah bergolongan darah $\mathrm{O}$ rhesus positif tidak jauh beda yaitu sebanyak 49 pendonor darah (34,51\%). Sedangkan data yang diperoleh dari UTD PMI Kabupaten Sleman bahwa pendonor bergolongan darah $\mathrm{O}$ rhesus positif lebih banyak mendonorkan darahnya yaitu sebanyak 4.406 pendonor darah dan pendonor bergolongan darah B rhesus positif sebanyak 2.775 pendonor darah. Golongan darah rhesus negatif tidak ditemukan pada pendonor darah yang gagal pengambilan darah. Tidak adanya rhesus negatif sangat berkaita dengan ras. Pada ras yang berkulit putih (warga Eropa, Amerika, dan Australia) jumlah pemilik rhesus negatif sekitar $15-18 \%$. Sedangkan pada ras Asia, persentase pemilik rhesus negatif jauh lebih kecil. Secara umum golongan darah rhesus yang paling banyak ditemukan di Indonesia adalah rhesus positif, hanya kurang dari $1 \%$ dari jumlah penduduk Indonesia yang memiliki rhesus negatif (Raihanun et al., 2019). Karena persentasenya yang sangat kecil sehingga pemilik rhesus negatif pada populasi ini tidak ditemukan.
Karakteristik pendonor darah yang gagal dilakukan pengambilan darah menurut jumlah donasi di UTD PMI Kabupaten Sleman Tahun 2019 sebagai berikut.

\begin{tabular}{|c|c|c|}
\hline $\begin{array}{l}\text { Jumlah } \\
\text { Donasi Darah }\end{array}$ & $\begin{array}{c}\text { Frekuensi } \\
(n=142)\end{array}$ & Persentase \\
\hline $\begin{array}{l}\text { Pendonor Baru } \\
\text { Pendonor }\end{array}$ & 69 & $48,59 \%$ \\
\hline Ulang & 73 & $51,41 \%$ \\
\hline Total & 142 & $100 \%$ \\
\hline
\end{tabular}

Berdasarkan tabel 5 terlihat bahwa jumlah pendonor darah baru yang gagal dilakukan pengambilan darah di UTD PMI Kabupaten Sleman tahun 2019 yaitu sejumlah 69 pendonor darah (48.59\%), sedangkan jumlah pendonor darah ulang yang gagal dilakukan pengambilan darah di UTD PMI Kabupaten Sleman tahun 2019 yaitu sejumlah 73 pendonor darah (51.41\%).

Pada hasil penelitian karakteristik pendonor darah yang gagal pengambilan darah menurut jumlah donasi darah di UTD PMI Kabupaten Sleman tahun 2019, dari 142 pendonor darah yang gagal pengambilan darah, pendonor darah ulang (> 1 kali donor darah) termasuk yang paling banyak gagal dilakukan pengambilan darah yaitu sebanyak $51,41 \%$ (73 pendonor darah). Dan untuk pendonor darah baru (1 kali donor darah) tidak jauh beda yaitu sebanyak 48,59\% (69 pendonor darah). Hasil ini sesuai dengan data yang diperoleh dari UTD PMI Kabupaten Sleman bahwa pendonor ulang ( $>1$ kali donor darah) lebih banyak mendonorkan darahnya yaitu sebanyak 7.443 pendonor darah, daripada pendonor baru (1 kali donor darah) sebanyak 4.057 pendonor darah. Pada pendonor baru (1 kali donor darah) persentasenya tidak jauh beda dengan pendonor ulang (> 1 kali donor darah), hal tersebut bisa disebabkan karena baru pertama kali mendonorkan darahnya dan masih merasa takut untuk donor darah, disuntik atau melihat darah yang dapat memicu reaksi tubuh seperti pusing, mual dan muntah, serta bisa sampai pingsan (Andrian, 2019). Sehingga mengharuskan untuk menghentikan proses pengambilan 
darah dan tidak terpenuhinya satu kantong darah yang penuh.

Jika sudah dilakukan dua kali penusukan vena pada kedua lengan pendonor darah dan belum didapatkan volume satu kantong darah yang penuh sesuai dengan maka pengambilan darah yang dilakukan termasuk gagal. Tidak boleh ada penusukan berulang atau dua kali pada lengan yang sama. Darah yang tidak memenuhi volume yang sudah ditentukan sesuai standart akan dikumpulkan dan kemudian dimusnahkan oleh UTD itu sendiri atau bekerjasama dengan fasilitas pelayanan kesehatan lainnya yang mempunyai sarana untuk pengolahan limbah (Menteri Kesehatan RI, 2014). Alat yang bisa digunakan untuk memusnahkan darah yaitu incinerator, mesin yang digunakan untuk membakar sampah dengan teknologi pengolahan sampah yang melibatkan pembakaran bahan organik dengan temperature tinggi yang mengubah sampah tersebut menjadi abu, uap, gas, dan panas (Achmad et al., 2017).

\section{KESIMPULAN}

Karakteristik pendonor darah yang gagal pengambilan darah didominasi oleh kelompok pendonor darah berjenis kelamin laki-laki, usia 17-25 tahun, golongan darah B rhesus positif, dan pendonor darah ulang.

\section{UCAPAN TERIMA KASIH}

UTD PMI Kabupaten Sleman yang telah memberikan izin untuk melakukan penelitian di UTD PMI Kabupaten Sleman.

\section{REFERENSI}

Achmad, S. N., Nugroho, R. A., Mardiyah, I., \& Oktaviana, N. (2017). Rancang Bangun Insenerator Limbah Medis Berteknologi Plasma Sebagai Filter Udara Hasil Pembakaran Limbah Medis. 8th Industrial Reasearch Workshop and National Seminar Politeknik Negeri Bandung, 575-579.

Alvira, N., \& Danarsih, D. E. (2016). Frekuensi Donor Darah Dapat Mengendalikan Faktor Resiko Penyakit Kardiovaskuler di Unit Donor Darah PMI Kabupaten Bantul. Jurnal Formil (Forum Ilmiah) KesMas Respati, l(1).
Andrian, K. (2019). Memahami Phobia Darah dan Penangananya. Alodokter, 1.

Astuti, Y., \& Artini, D. (2019). Pemeriksaan golongan darah dan kadar hemoglobin pada calon pendonor darah di Puslatpur, Playen, Gunungkidul. Jurnal Pemberdayaan: Publikasi Hasil Pengabdian Kepada Masyarakat, 3(3), 433-438. https://doi.org/https://doi.org/10.12928/jp.v3i 3.1216

Buowari, O. Y. (2013). Complications of venepuncture. Advances in Bioscience and Biotechnology, 2013(January), 126-128.

Depkes RI. (2009). Kategori Usia. http://kategori-umur-menurut-depkes.html

Depkes RI. (2017). Indonesia Butuh Darah 5,1 Juta Kantong Pertahun. Depkes RI. https://www.depkes.go.id/article/print/17071 100002/indonesia-butuh-darah-5-1-jutakantong-pertahun.html

Dhingra, N., Diepart, M., Dziekan, G., Khamassi, S., Otaiza, F., Wilburn, S., AlAbdulrazzak, R., Bertsche, P. K., Damani, N., Lin, C.-K., Marum, L., Mehtar, S., Perz, J., Pietersz, R., Reed, C., Selenic, D., \& Wiersma, S. (2010). WHO guidelines on drawing blood: best practices in phlebotomy (H. Cadman (ed.)). World Health Organization.

Kiswari, R. (2014). Hematologi \& Transfusi (S. Carolina \& R. Astikawati (eds.)). Erlangga.

Kumlasari, N. L. G. Y., \& Lestari, A. A. W. (2015). Gambaran Karakteristik Pendonor, Prevelensi Infeksi HIV, Prevelensi Infeksi Sifilis, Pada pendonor Pengganti dan Pendonor Sukarela di Unit Donor Darah Provinsi Bali-RSUP Sanglah Tahun 2013. EJurnal Medika Udayana, 4(11).

Mawarni, Y. (2015). Pertanggungjawaban Pelaku Donor Bayaran. Thesis, 91. http://repository.unair.ac.id/id/eprint/79147

Mbah, H. A. (2014). Phlebotomy and quality in the African laboratory. African Journal of Laboratory Medicine, 3(1), 4-7. https://doi.org/10.4102/ajlm.v3i1.132

Menteri Kesehatan RI. (2014). Peraturan Menteri Kesehatan Republik Indonesia Nomor 83 Tahun 2014 Unit Transfusi Darah, Bank Darah Rumah Sakit dan Jejaring Pelayanan Transfusi Darah. Menteri Kesehatan Republik Indonesia.

Menteri Kesehatan RI. (2016). Peraturan Menteri Kesehatan Republik Indonesia Nomor 91 Tahun 2015 Tentang Standart Pelayanan Darah (Issue 36).

Nasir, A., Muhith, A., \& Ideputri, M. E. (2014). 
Buku Ajar Metodologi Penelitian Kesehatan: Konsep Pembuatan Karya Tulis Ilmiah dan Thesis untuk Mahasiswa Kesehatan (Haikhi (ed.)). Nuha Medika.

Notoatmodjo, S. (2012). Metodologi Penelitian Kesehatan (Kedua). Rineka Cipta.

Noviar, G. (2018). Komponen Darah. In Bahan Ajar Teknologi Laboratorium Medik (TLM): Imunohematologi dan Bank Darah (Pertama, pp. 79-143). Kementrian Kesehatan Republik Indonesia.

Poetri, R. A. S. (2014). Keterampilan Dasar Klinik II: Pengambilan Spesimen Darah Vena pada Nn. Bw Di Ruang Kasuari I RSUD Kabupaten Sorong (p. 42). Politeknik Kesehatan Kemenkes Sorong.

Presiden RI. (2011). Peraturan Pemerintah Republik Indonesia Nomor 7 Tahun 2011 Pelayanan Darah.

Pusdatin Kemenkes. (2015). Situasi Pelayanan Darah di Indonesia (p. 8). Kementrian Kesehatan Republik Indonesia.

Pusdatin Kemenkes. (2018). Pelayanan Darah di Indonesia (p. 7). Kementrian Kesehatan Republik Indonesia.

Rachman, F. S., \& Aditya, R. N. (2013). Question \& Answers Donor Darah (Pertama). PT Elex Media Komputindo. https://doi.org/170130716

Raihanun, S., Mentari, D., Wulandari, M., \& Pebrina, R. (2019). Gambaran Golongan Darah ABO-Rhesus dan Pola Sidik Jari Pada Mahasiswa Program Studi D-3 Teknologi Transfusi Darah STIKES Guna Bangsa Yogyakarta. Journal of Health, 5(2), 105111.

Sinde, M. S. (2014). Gambaran Pengetahuan Sikap dan Motivasi Mengenai Donor Darah pada Donor Darah Sukarela di Unit Donor Darah Kota Pontianak.

Sonita, A., \& Kundari, R. (2019). Aplikasi Seleksi Calon Pendoonor darah Menggunakan Algoritme C4.5. Jurnal Pseudocode, VI. https://ejournal.unib.ac.id/index.php/pseudo code/article/view/6934/4577

Supadmi, F. R. S. (2019). Modul Praktikum: Pengambilan Darah Pendonor (1st ed.). Program Studi Teknologi Bank Darah Fakultas Kesehatan Universitas Jenderal Achmad Yani Yogyakarta.

Vuk, T. (2011). The management of nonconformities in blood establishments. International Society of Blood Transfusion (ISBT) Science Series, 6, 30-34.

Vuk, T., Cipek, V., \& Jukić, I. (2015). Blood collection staff education in the prevention of venepuncture failures and donor adverse reactions: From inexperienced to skilful staff. Blood Transfusion, 13(2), 338-339. https://doi.org/10.2450/2014.0216-14 